\title{
Formoterol versus montelukast as add on therapy to low dose budesonide in persistent asthma: effect on lung function
}

\author{
Divya G. Krishnan ${ }^{1 *}$, Anukesh Vasu Keloth ${ }^{2}$
}

${ }^{1}$ Department of Pharmacology, ${ }^{2}$ Department of Surgery, KMCT Medical College, Kozhikode, Kerala, India

Received: 15 April 2018 Accepted: 04 May 2018

*Correspondence to:

Dr. Divya G. Krishnan, Email: dgkindia@gmail.com

Copyright: (C) the author(s), publisher and licensee Medip Academy. This is an openaccess article distributed under the terms of the Creative Commons Attribution NonCommercial License, which permits unrestricted noncommercial use, distribution, and reproduction in any medium, provided the original work is properly cited.

\begin{abstract}
Background: Choice between LABAs and LTRAs as add on drugs to low dose ICS in persistent asthma remains unclear due to limited data on the comparative efficacy of these two groups of drugs. The aim of this study was to compare the effects of formoterol and montelukast on lung function, when added to low dose Budesonide in persistent asthma.

Methods: This was an institution based randomized open label study. 72 asthmatics satisfying selection criteria of the study were randomized to receive either inhaled budesonide and formoterol (FB group) or inhaled budesonide and oral montelukast (MB group) for 12 weeks. PEF value at end point was primary efficacy measure. Secondary efficacy measures were PEF values measured at the end of 1, 4 and 8 weeks and the end point value of FEV1.

Results: Both the groups showed significant improvement in the lung function tests. However inter-group comparison showed that PEF value at end point of FB group was significantly greater than that of MB group $(81.94 \%$ vs $63.82 \%$, $\mathrm{p}<0.05)$. Notable observation was that the superiority of the FB group with respect to PEF values was maintained from the first week itself. FB group also had significantly better results than MB group for FEV1 (67.88\% vs $64.88 \%$, $\mathrm{p}<0.05)$.

Conclusions: In the present study, formoterol was found to be superior to montelukast in improving lung function when added to low dose budesonide in persistent asthma.
\end{abstract}

Keywords: Budesonide, Formoterol, Lung function, Montelukast

\section{INTRODUCTION}

Inhaled corticosteroids (ICS) represent the most effective controller medications in persistent asthma. In patients who are not controlled by low dose ICS alone, Global Initiative for Asthma (GINA) guidelines recommend either escalating the dose of inhaled corticosteroids (ICS) or the addition of a second controller drug in the form of long acting beta 2 agonist (LABA) or leukotriene receptor antagonist (LTRA) to low dose ICS. Due to side effects at higher doses of ICS, the option of adding a second controller drug to low dose ICS is preferred. ${ }^{1}$ However, LABAs and LTRAs are characterized by markedly different pharmacologic properties that can bring about different effects on the basic mechanisms of the disease. ${ }^{2,3}$ Also the data available on the comparative efficacy of these two groups of drugs is largely contrasting. Hence, in this study we compared the effects of a LABA like formoterol and an LTRA like montelukast on lung function, when added to low dose ICS like budesonide in persistent asthma.

\section{METHODS}

This randomized open label comparative study was conducted at a tertiary centre in Kerala after getting ethical clearance from the Institutional Ethics committee. Authors 
included 72 subjects recruited from the outpatient department of Pulmonology. Male and female asthmatics aged between 18 to 60 years of age whose asthma was inadequately controlled despite receiving regular low dose inhaled Budesonide (i.e. at a dose of $400 \mu \mathrm{g} /$ day) for atleast 6 weeks prior to screening, were eligible for inclusion in the study. Asthma control in patients was considered inadequate if their lung function i.e. Peak expiratory flow (PEF) or Forced expiratory volume at the end of $1^{\text {st }}$ second (FEV1) before administration of a bronchodilator was less than $80 \%$ of the predicted value on the day of randomization. ${ }^{1}$ Pregnant and lactating women, smokers, patients with accompanying respiratory tract infections, patients who received treatment with oral steroids/mast cell stabilizers/ LTRAs/ LABAs or oral short acting beta 2 agonists in the month preceding the screening and patients with history of hypertension/diabetes/heart disease or other co-morbid conditions requiring concurrent medications were not included in the study. Patients whose (PEF or FEV1) was less than $80 \%$ of the predicted value on the day of screening entered a 2 week run in period during which period they used $200 \mu$ g Budesonide twice daily through a metered dose inhaler. After the run in period, patients who satisfied the aforesaid inclusion criteria on the day of randomization were enrolled in the study after obtaining written informed consent. The enrolled patients were randomly divided into two groups using the block randomization technique. Both the groups were treated for 12 weeks. The first intervention group (FB group) was prescribed a combination of inhaled Budesonide and Formoterol $(200 \mu \mathrm{g}+6 \mu \mathrm{g} / \mathrm{puff})$, one puff twice daily through a metered dose inhaler and the second intervention group (MB group) was prescribed inhaled

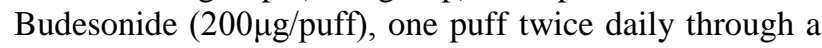
metered dose inhaler and an oral dose of Montelukast (10mg) in the evening. ${ }^{4,5}$ Patient compliance was assured by asking them to bring empty packages of medicines and also from the history. Patients who developed severe asthma exacerbations requiring an unscheduled visit to the doctor, emergency room, hospital admission or treatment beyond the drugs included in the study were withdrawn from the study. The efficacy parameters were recorded at baseline (i.e. at randomization) and at the follow up visits scheduled at the end of $1,4,8$ and 12 weeks by spirometry. In this study, the pre-specified primary efficacy measure was PEF measured at 12 weeks. PEF values measured at the end of 1 week, 4 weeks and 8 weeks and the end point values of FEV1 were considered as secondary efficacy measures. Patients who completed the entire 12 weeks of treatment period were included in the statistical analysis. Statistical analysis was done by applying $\mathrm{t}$ test and estimating ' $p$ ' value using Statistical package for social service (SPSS) software. The p value of less than 0.05 was considered statistically significant.

\section{RESULTS}

After screening assessment and 2 weeks run in period, 72 patients were randomized into 2 groups of 36 each to receive either of the treatments for 12 weeks. There were
2 drop outs from each group. 68 patients satisfactorily completed the treatment period and were included in the main analysis.

Authors compared the mean values of the efficacy parameters of the study groups at baseline using Independent $t$ test (Table 1) and found them to be comparable ( $\mathrm{p}$ value of each parameter being more than $0.05)$.

Table 1: Baseline comparison of efficacy parameters of the study groups (Independent $t$ test).

\begin{tabular}{|c|c|c|c|c|c|}
\hline $\begin{array}{l}\text { Efficacy } \\
\text { parameter }\end{array}$ & Group & $\begin{array}{l}\text { Mea } \\
\text { n }\end{array}$ & SD & $\mathbf{t}$ & $\begin{array}{l}\text { p } \\
\text { Value }\end{array}$ \\
\hline \multirow{2}{*}{$\begin{array}{l}\text { PEF (\% } \\
\text { predicted) }\end{array}$} & $\begin{array}{l}\text { FB } \\
\text { group }\end{array}$ & 61.88 & 4.816 & \multirow{2}{*}{-0.915} & \multirow{2}{*}{0.363} \\
\hline & $\begin{array}{l}\text { MB } \\
\text { group }\end{array}$ & 63.47 & 4.919 & & \\
\hline \multirow{2}{*}{$\begin{array}{l}\mathrm{FEV}_{1}(\% \\
\text { predicted) }\end{array}$} & $\begin{array}{l}\text { FB } \\
\text { group }\end{array}$ & 56.88 & 3.427 & \multirow{2}{*}{-1.921} & \multirow{2}{*}{0.059} \\
\hline & $\begin{array}{l}\text { MB } \\
\text { group }\end{array}$ & 59.12 & 5.856 & & \\
\hline
\end{tabular}

Authors compared the baseline and end point values of PEF and FEV1 in each of the groups to assess the improvement in each group. Both the groups showed significant increase in the PEF and FEV1 values (Tables 2 and 3 ).

Table 2: Comparison of baseline and end point values of efficacy parameters of FB group (paired $t$ test).

\begin{tabular}{|c|c|c|c|c|c|}
\hline $\begin{array}{l}\text { Efficacy } \\
\text { parameter }\end{array}$ & & Mean & SD & $\mathbf{t}$ & p value \\
\hline \multirow[b]{2}{*}{$\begin{array}{l}\text { PEF(\% pred } \\
\text { icted) }\end{array}$} & Baseline & \multirow[b]{2}{*}{20.06} & \multirow[b]{2}{*}{0.78} & \multirow[b]{2}{*}{25.69} & \multirow[b]{2}{*}{$<0.00001$} \\
\hline & $\begin{array}{l}\text { End } \\
\text { point }\end{array}$ & & & & \\
\hline \multirow{2}{*}{$\begin{array}{l}\text { FEV1(\%pr } \\
\text { edicted) }\end{array}$} & Baseline & \multirow[b]{2}{*}{11.00} & \multirow[b]{2}{*}{0.13} & \multirow[b]{2}{*}{82.39} & \multirow[b]{2}{*}{$<0.00001$} \\
\hline & $\begin{array}{l}\text { End } \\
\text { point }\end{array}$ & & & & \\
\hline
\end{tabular}

Table 3: Comparison of baseline and end point values of efficacy parameters of MB group (paired $t$ test).

\begin{tabular}{|c|c|c|c|c|c|}
\hline $\begin{array}{l}\text { Efficacy } \\
\text { parameter }\end{array}$ & & Mean & SD & $\mathbf{t}$ & p value \\
\hline \multirow[b]{2}{*}{$\begin{array}{l}\text { PEF(\%pre } \\
\text { dicted) }\end{array}$} & Baseline & \multirow[b]{2}{*}{10.82} & \multirow[b]{2}{*}{0.45} & \multirow[b]{2}{*}{23.96} & \multirow[b]{2}{*}{$<0.00001$} \\
\hline & $\begin{array}{l}\text { End } \\
\text { point }\end{array}$ & & & & \\
\hline \multirow[b]{2}{*}{$\begin{array}{l}\text { FEV1 }(\% \text { pr } \\
\text { edicted })\end{array}$} & Baseline & \multirow[b]{2}{*}{05.56} & \multirow[b]{2}{*}{0.17} & \multirow[b]{2}{*}{32.72} & \multirow[b]{2}{*}{$<0.00001$} \\
\hline & $\begin{array}{l}\text { End } \\
\text { point }\end{array}$ & & & & \\
\hline
\end{tabular}

Authors compared the primary efficacy measure (PEF at end point) of the two groups using Independent $t$ test. At the end point, mean values of PEF of both the groups increased, reaching $81.94 \%$ in the FB group and $73.82 \%$ in the $\mathrm{MB}$ group but the mean value of $\mathrm{FB}$ group was 
significantly higher than that of MB group $(\mathrm{p}<0.05)$ (Table 4 and Figure 1).

Table 4: Inter group comparison of primary efficacy measure (Independent t test).

\begin{tabular}{|c|c|c|c|c|c|}
\hline $\begin{array}{l}\text { Primary } \\
\text { efficacy } \\
\text { measure }\end{array}$ & Group & Mean & SD & $\mathbf{t}$ & $\begin{array}{l}p \\
\text { value }\end{array}$ \\
\hline \multirow{2}{*}{$\begin{array}{l}\text { PEF (\% } \\
\text { predicted) } \\
\text { at end } \\
\text { point }\end{array}$} & $\begin{array}{l}\text { FB } \\
\text { group }\end{array}$ & 81.94 & 1.705 & \multirow{2}{*}{10.498} & \multirow{2}{*}{0.000} \\
\hline & $\begin{array}{l}\text { MB } \\
\text { group }\end{array}$ & 73.82 & 4.174 & & \\
\hline
\end{tabular}

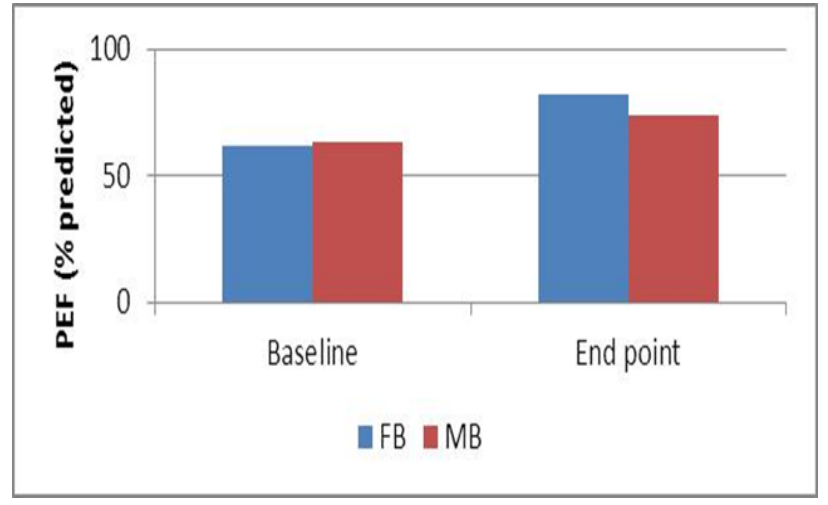

Figure 1: Comparison of mean values of PEF of the study groups at baseline and end point.

Table 5: Inter group comparison of secondary efficacy measures (Independent t test).

\begin{tabular}{|c|c|c|c|c|c|}
\hline Secondary efficacy measure & Group & Mean & SD & $\mathbf{t}$ & p value \\
\hline PEF (\% predicted) at end of & FB group & 67.74 & 3.662 & & \\
\hline 1week & MB group & 63.47 & 4.919 & 4.055 & 0.000 \\
\hline PEF ( $\%$ predicted) at end of 4 & FB group & 70.85 & 2.956 & & \\
\hline weeks & MB group & 65.53 & 4.494 & 5.771 & 0.000 \\
\hline PEF ( $\%$ predicted) at end of 8 & FB group & 76.82 & 2.236 & & \\
\hline weeks & MB group & 69.65 & 4.320 & 8.603 & 0.000 \\
\hline \multirow{2}{*}{$\mathrm{FEV}_{1}(\%$ predicted $)$ at end point } & FB group & 67.88 & 3.255 & \multirow{2}{*}{2.825} & \multirow{2}{*}{0.006} \\
\hline & MB group & 64.68 & 5.762 & & \\
\hline
\end{tabular}

The secondary efficacy measures were compared in a similar manner. The FB group had significantly better results for each of the secondary efficacy measures (Tables 5, Figure 2 and Figure 3).

Mean values of PEF continued to increase in both the groups from the start of the study till the end point. At all times, the values of FB group were significantly greater than those of the MB group (Figure 4).

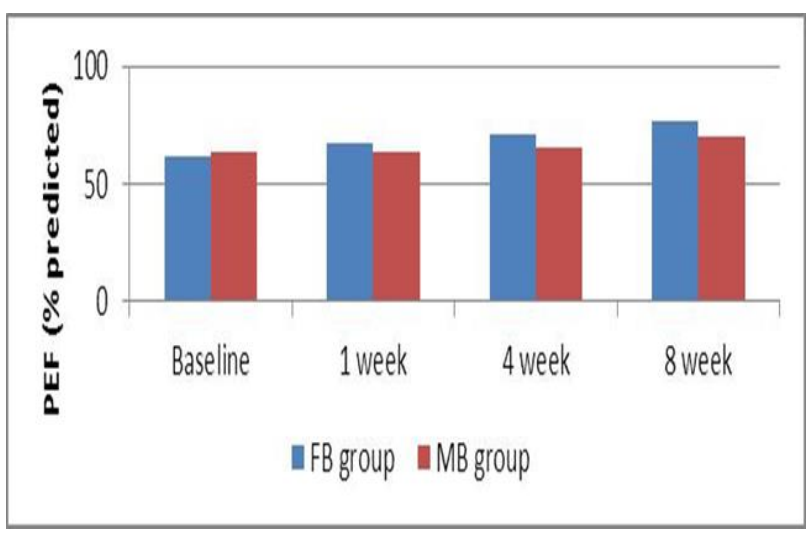

Figure 2: Comparison of mean values of PEF of the study groups at baseline, at the end of 1week, 4 weeks and 8 weeks.

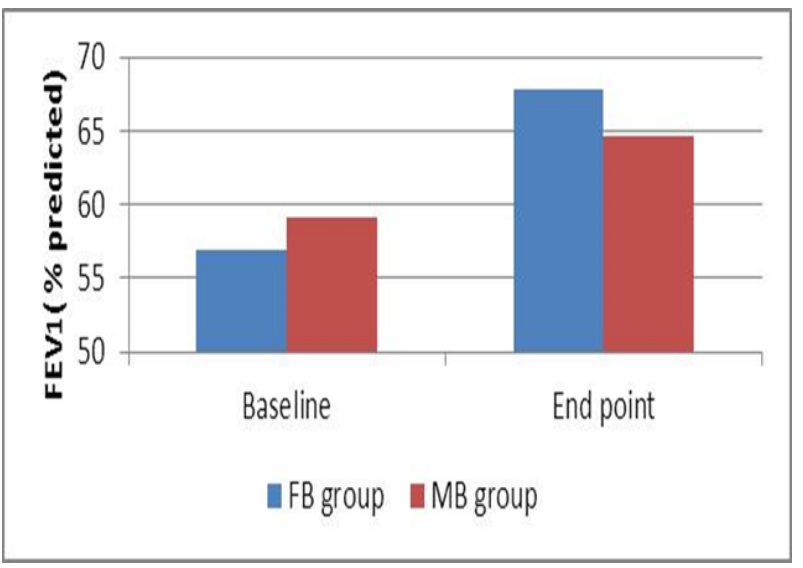

Figure 3: Comparison of mean values of FEV1 of the study groups at baseline and end point.

\section{DISCUSSION}

Asthma is a public health problem affecting $4.3 \%$ of the adult population globally. ${ }^{6}$ Inhaled corticosteroids (ICS) are the first line controller treatment of persistent asthma. Though low dose ICS are effective in most patients, some remain symptomatic despite the therapy. Treatment in these patients is stepped up by either increasing the dose of inhaled corticosteroids or by adding a concomitant 
second drug to supplement the effect of the low dose ICS. As higher doses of ICS are associated with greater adverse effects, the option of adding a concomitant second drug like LABA or LTRA to low dose ICS is recommended by international guidelines. ${ }^{1}$

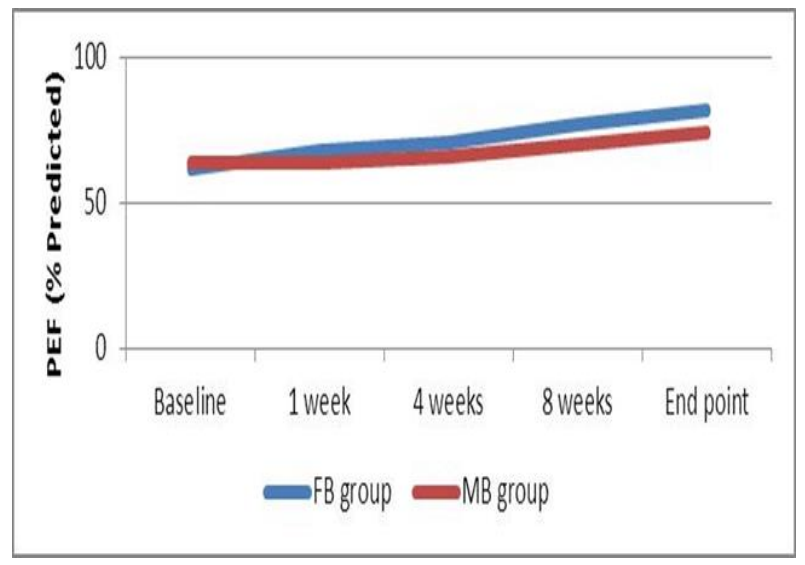

Figure 4: Mean values of PEF of the study groups from the start to end of treatment.

LABAs and LTRAs have been separately compared with placebo and with increased doses of inhaled corticosteroids and many a time been proved to be therapeutically superior or similar. ${ }^{7-10}$ However choice between these two groups of drugs is not easy as there is limited data on the comparative efficacy and safety of these two groups of drugs.

Out of the 72 patients enrolled in this study, 68 patients satisfactorily completed the treatment period. This high rate of response can be attributed to the motivation of patients by the investigator and the free supply of medicines.

In this study, both the groups had significant improvement in the PEF and FEV1 values at the end of the study. The data from the present study however is in contrast with that presented by Buchvald et al, and Nelson et al, wherein the group treated with LABA was the only one with significant increase in lung function, whereas the improvement in the lung function of the group treated with LTRA was not significant. ${ }^{11,12}$ However, in the study done by Straub et al, add on therapy with montelukast brought about significant improvement in lung function. ${ }^{13}$

As per our study, the FB group showed significantly greater improvement in PEF and FEV1. This is in accordance with studies done by Ringdal et al, Ceylan et al. ${ }^{14,15}$ The fact that mean values of PEF of FB group were significantly greater than that of $\mathrm{MB}$ group throughout the study period showed that FB treatment was better than MB treatment in improving lung function right from the first week after the start of the respective treatments. This significant superiority of LABA over LTRA in improving PEF at a much earlier point in the course of treatment was also shown in the 2 week study by Wilson and his colleagues. $^{16}$

A notable finding of this study was that PEF values continued to increase during the course of the 12 week study period in both the groups and that the values did not plateau for either of the groups at the end of 12 weeks (Figure 4). This was in contradiction to the study by Fish et al wherein PEF values reached a plateau for both the groups at the end of 12 weeks. ${ }^{17}$

\section{CONCLUSION}

Thus, authors conclude that both formoterol and montelukast bring about significant improvements in lung function when added to low dose budesonide. However, inter- group comparison shows formoterol to be the better therapeutic option than montelukast. The fact that the PEF values for both groups did not plateau at the end of the study period warrants the need for future studies of longer duration to assess whether this treatment related difference persists for a longer period of time.

\section{ACKNOWLEDGEMENTS}

Authors would like to acknowledge all the participants for sparing their valuable time for betterment of science.

Funding: No funding sources

Conflict of interest: None declared

Ethical approval: The study was approved by the Institutional Ethics Committee

\section{REFERENCES}

1. GINA workshop report. Global strategy for asthma management and prevention, updated 2012: scientific information and recommendations for asthma programs. Bethesda, MD: National Institutes of Health; publication No., 02-3659.

2. Barnes PJ. Scientific rationale for inhaled combination therapy with long-acting beta2-agonists and corticosteroids. Eur Respir J. 2002;19:182-91.

3. Hay DW. Pharmacology of leukotriene receptor antagonists. More than inhibitors of bronchoconstriction. Chest. 1997;111:35S-45S.

4. Sweetman SC, Blake DS, Brayfield A, Mc Glashan JM, Nethercoat GC, Parsons AV. Corticosteroids. In: Martindale: the complete drug reference. 36th ed. London: Pharmaceutical press; 2009:1499-1546.

5. Sweetman SC, Blake DS, Brayfield A, Mc Glashan JM, Nethercoat GC, Parsons AV, et al, editors. Bronchodilators and anti-asthma drugs. In: Martindale: the complete drug reference. $36^{\text {th }}$ Ed. London: Pharmaceutical press; 2009:1108-1151.

6. Teresa TO, Stanojevic S, Moore G, Andrea S, Eric D, Alvaro A, et al. Global asthma prevalence in adults: findings from the cross sectional world health survey. BMC public health. 2012;12:2047. 
7. Pauwels RA, Lofdahl CG, Postma DS, Tattersfield AE, O'Byrne P, Barnes PJ, et al. Formoterol and Corticosteroids Establishing Therapy (FACET) International Study Group: Effect of inhaled Formoterol and Budesonide on exacerbations of asthma. N Engl J Med. 1997;337:1405-11.

8. Lalloo UG, Malolepszy J, Kozma D, Krofta K, Ankerst J, Johansen B, Thomson NC. Budesonide and Formoterol in a single inhaler improves asthma control compared with increasing the dose of corticosteroid in adults with mild-to-moderate asthma. Chest. 2003;123:1480-7.

9. Price DB, Hernandez D, Magyar P, Filterman J, Beeh KM, James IG. Clinical outcomes with Montelukast as a partner agent to corticosteroid therapy (COMPACT) International study group: Randomized controlled trial of Montelukast plus inhaled budesonide versus double dose inhaled Budesonide in adult patients with asthma. Thorax. 2003;58:211-6.

10. Vaquerizo MJ, Casan P, Castillo, Perpina M, Sanchis, Sobradillo V. Effect of added Montelukast to inhaled Budesonide on control of mild to moderate asthma. Thorax. 2003;58:204-11.

11. Buchvald F, Bisgaard H. Comparisons of the complementary effect on exhaled nitric oxide of salmeterol vs montelukast in asthmatic children taking regular inhaled budesonide. Ann Allergy Asthma Immunol. 2003;91:309-13.

12. Nelson HS, Busse WW, Kerwin E, Church N, Amanda E, Kathleen R, et al. Fluticasone propionate/Salmeterol combination provides more effective asthma control than low-dose inhaled corticosteroid plus Montelukast. J Allergy ClinImmunol. 2000;106:1088-95.

13. Straub DA, Minocchieri S, Moeller A, Hamacher J, Wildhaber JH. The effect of montelukast on exhaled nitric oxide and lung function in asthmatic children 2 to 5 years old. Chest. 2005;127:509-14.

14. Ringdal N, Eliraz A, Pruzinec P, Weber HH, Mulder PG, Akveld M, et al. The Salmeterol/Fluticasone combination is more effective than Fluticasone plus oral Montelukast in asthma. Resp Med. 2003;97:23441.

15. Ceylan E, Gencer M, Aksoy S. Addition of Formoterol or Montelukast to low dose Budesonide: An efficacy comparison in short and long term asthma control. Respiration. 2004;71:594-601.

16. Wilson AM, Dempsey OJ, Sims EJ, Lipworth BJ. Evaluation of Salmeterol or Montelukast as second line therapy for asthma not controlled with inhaled corticosteroids. Chest. 2001;119(4):1021-6.

17. Fish JE, Israel E, Murray JJ, Emmett A, Boone R, Yancey SW, et al. Salmeterol powder provides significantly better benefit than Montelukast in asthmatic patients receiving concomitant inhaled corticosteroid therapy. Chest. 2001;120(2):423-30.

Cite this article as: Krishnan DG, Keloth AV.

Formoterol versus montelukast as add on therapy to low dose budesonide in persistent asthma: effect on lung function. Int J Basic Clin Pharmacol 2018;7:1186-90. 